\title{
Ingestive behavior of heifers in Alexandergrass pasture receiving different amounts of oat grain as supplement
}

\section{Comportamento ingestivo de novilhas em pastagem de capim papuã recebendo suplementos em diferentes níveis}

\author{
Maria José de Oliveira Sichonany ${ }^{1 *}$; Marta Gomes da Rocha²; Luciana Pötter²; \\ Ana Paula Binato Beltrão de Oliveira ${ }^{1}$; Laila Arruda Ribeiro ${ }^{1}$; \\ Mônique Foggiato da Silva ${ }^{1}$; Anelise Pereira Hundertmarck ${ }^{1}$; \\ Paulo Roberto Salvador ${ }^{1}$
}

\begin{abstract}
This study was conducted to evaluate the ingestive behavior, displacement patterns and meal dynamics of beef heifers in Alexandergrass pasture (Urochloa plantaginea (Link.) Hitch) receiving different amounts of oat grain: $0,0.80$ and $1.12 \%$ of body weight (BW). The grazing method was continuous with put-and-take stocking. The experimental design was completely randomized following a repeated measure arrangement. The grazing time decreased and the idling time increased when beef heifers were supplemented, independently of supplement amount, while the rumination time was similar across supplement amounts. The number of feeding stations per minute and the number of steps taken between each feeding station were similar regardless of supplementation. When receiving $1.12 \%$ of BW of oat grain, heifers remained longer in each feeding station and took fewer steps per minute. The number of meals decreased and the duration of breaks between meals increased when heifers received oat grain. The duration of each meal was similar for heifers receiving supplement than for those that did not. Understanding how animals adjust their grazing behavior and cope with changing environmental dynamics is essential for the development of management strategies designed to optimize animal production.
\end{abstract}

Key words: Avena sativa, continuous grazing, feeding station, Urochloa plantaginea (Link.) Hitch

\section{Resumo}

Foi estudado o comportamento ingestivo, os padrões de deslocamento e a dinâmica de refeições de novilhas de corte em pastagem de papuã (Urochloa plantaginea (Link.) Hitch) recebendo diferentes quantidades de grão de aveia: 0; 0,80 e 1,12\% do peso corporal (PC). O método de pastejo foi continuo com número variável de animais. O delineamento experimental foi o inteiramente casualizado com medidas repetidas no tempo. O tempo de pastejo diminuiu e o de outras atividades aumentou quando novilhas de corte foram suplementadas, independente da quantidade, mantendo semelhante o tempo de ruminação. O número de estações alimentares por minuto e número de passos realizados entre cada estação alimentar foram semelhantes quando as novilhas receberam ou não suplemento. Ao receber

\footnotetext{
${ }^{1}$ Discentes do Programa de Pós-Graduação em Zootecnia, Universidade Federal de Santa Maria, UFSM, Santa Maria, RS, Brasil. E-mail: maria_sichonany@hotmail.com; anapauloagro2012@gmail.com; laila-aribeiro@hotmail.com; monique_zootecnia@ hotmail.com; nisaph@hotmail.com; paulo.r.salvador@hotmail.com

2 Profs., Programa de Pós-Graduação em Zootecnia, UFSM, Santa Maria, RS, Brasil. E-mail: mgdarocha@gmail.com; potter. luciana@gmail.com

* Author for correspondence
} 
$1,12 \%$ do PC de grão de aveia as novilhas permaneceram mais tempo em cada estação alimentar e realizaram menor número de passos por minuto. $\mathrm{O}$ número de refeições alimentares foi reduzido e aumentou a duração do intervalo entre refeições quando as novilhas receberam grão de aveia. A duração de cada refeição foi similar para novilhas que receberam suplemento ou exclusivamente em pastejo.

Palavras-chave: Avena sativa, pastejo contínuo, tempo por estação alimentar, Urochloa plantaginea (Link.) Hitch

\section{Introduction}

The way herbivores search for and apprehend forage makes up what is known as ingestive grazing behavior and is related to the controlled management of pasture. Through ingestive behavior, the ruminant adapts to different environmental and management features to meet their nutritional requirements, which is reflected in these animals' performance.

The daily grazing time of herbivores includes several meals. In order to predict nutrient acquisition by herbivores, one must understand the relationship between the structure of the pasture and the management of supplement provided to grazing animals, as well as the factors affecting the time spent at each feeding station, the number of feeding stations visited, the animal's displacement, and the number and duration of meals (BAUMONT et al., 2000).

Alexandergrass (Urochloa plantaginea (Link.) Hitch) has a high potential for producing quality forage and yields productive performance, forage intake and intake of total digestible nutrients similar to those obtained with Pearl millet pasture (COSTA et al., 2011). In the summer, the energetic supplementation for animals in high quality pasture such as Alexandergrass synchronizes the rate of nitrogen supply to ruminants and can improve the utilization of protein from forage, which is rapidly degraded in the rumen, increases microbial protein synthesis, reduces nitrogen losses in the urine and can thus increase animal performance (REARTE; PIERONI, 2001). The supply of concentrate usually alters ingestive behavior (grazing, rumination and other activities, as well as bite rate and mass and meals), forage selection and searching patterns (KRYSL; HESS, 1993).

Understanding how animals adjust their grazing behavior and cope with changing environmental dynamics is essential for the development of management strategies designed to optimize animal production (KRYSL; HESS, 1993). Based on the hypothesis that supplements modify the ingestive behavior of heifers, the aim of this study was to evaluate the ingestive behavior, displacement patterns and the meal dynamics of beef heifers grazing Alexandergrass and receiving different amounts of supplement and to investigate the chemical characteristics of forage as grazed and the structural characteristics of the sward associated with these outcome variables.

\section{Material and Methods}

This study was carried out at the Federal University of Santa Maria (UFSM), located in the Central Depression of Rio Grande do Sul, Brazil, from January to March of 2011. The climate in the region is humid subtropical, according to the Köppen classification. The soil is classified as Paleudalf (EMBRAPA, 2006). The mean values for the chemical characteristics of the soil in the experimental area were: $\mathrm{pH}-\mathrm{H}_{2} \mathrm{O}: 5.0 ; \mathrm{pH}-\mathrm{SMP}$ : 5.8; clay: 19.2\% ; P: $13.4 \mathrm{mg} / \mathrm{L}$; K: $92 \mathrm{mg} / \mathrm{L}$; OM: $2.7 \% ; \mathrm{Al}^{3+}: 0.2$ cmolc/L; $\mathrm{Ca}^{2+}: 4.6$ cmolc/L; $\mathrm{Mg}^{2+}$ : $2.2 \mathrm{cmolc} / \mathrm{L}$; base saturation: $56.6 \%$; Al saturation: $3 \%$. The meteorological data for the months that comprised the experimental period were obtained from the UFSM Meteorological Station (Table 1). 
The experimental area was divided into six paddocks of 0.8 ha plus a contiguous area of 1.5 ha for the put-and-take animals. Alexandergrass (Urochloa plantaginea (Link.) Hitch) was established by an existing seed bank in the area in November 2010. The fertilizer consisted of 200 $\mathrm{kg} / \mathrm{ha}$ of the formula $05-20-20$ (NPK) and $80 \mathrm{~kg}$ of nitrogen $(\mathrm{N}) /$ ha in urea form, subdivided into three applications.

Table 1. Average monthly rainfall and temperature from January to April 2011 and normal history data, Santa Maria/ RS, Brazil.

\begin{tabular}{|c|c|c|c|}
\hline \multirow{2}{*}{ Items } & \multicolumn{3}{|c|}{ Month of evaluation } \\
\hline & January & February & March \\
\hline \multicolumn{4}{|l|}{ Observed } \\
\hline Maximum Temperature $\left({ }^{\circ} \mathrm{C}\right)$ & 32.4 & 29.9 & 28.4 \\
\hline Minimum Temperature $\left({ }^{\circ} \mathrm{C}\right)$ & 21.6 & 21.0 & 18.2 \\
\hline Average Temperature $\left({ }^{\circ} \mathrm{C}\right)$ & 25.6 & 24.6 & 22.5 \\
\hline Rainfall (mm) & 246.9 & 195.4 & 229.4 \\
\hline Insulation (h) & 127.1 & 165.8 & 54.9 \\
\hline \multicolumn{4}{|l|}{ History $^{1}$} \\
\hline Maximum Temperature $\left({ }^{\circ} \mathrm{C}\right)$ & 30.4 & 30.0 & 28.2 \\
\hline Minimum Temperature $\left({ }^{\circ} \mathrm{C}\right)$ & 19.1 & 19.5 & 17.9 \\
\hline Average Temperature $\left({ }^{\circ} \mathrm{C}\right)$ & 24.6 & 24.0 & 22.2 \\
\hline Rainfall (mm) & 145.1 & 130.2 & 151.7 \\
\hline Insulation (h) & 225.2 & 212.0 & 197.5 \\
\hline
\end{tabular}

${ }^{1}$ Average records from 1980 to 2011.

We evaluated the ingestive behavior, displacement patterns and meal dynamics of heifers kept exclusively on Alexandergrass pasture or supplemented with oat grain at a ratio of 0.80 or $1.12 \%$ of body weight. The supplement was provided daily at 9:00 a.m. and was composed of: $95.8 \%$ of dry matter (DM), $7.9 \%$ of mineral matter (MM), $92.1 \%$ of organic matter (OM), 33.4\% of neutral detergent fiber (NDF), $13.3 \%$ of crude protein (CP), $70.2 \%$ of total digestible nutrients (TDN) and in situ digestibility of DM 76.2\%.

The grazing method was put-and-take stocking (HERINGER; CARVALHO, 2002) to maintain 2.5 to $3 \mathrm{t} /$ ha DM of forage mass. The pasture utilization started on December $27^{\text {th }}, 2010$ and the animals were adapted to the place for nine days before the beginning of the experimental period. In each experimental unit, four Angus heifers with an initial age of 14 months and body weight of $252 \pm 28 \mathrm{~kg}$ were used.

The forage mass (FM; $\mathrm{kg}$ of $\mathrm{DM} / \mathrm{ha}$ ) was evaluated every 14 days by the direct visual estimation method with double sampling. The canopy height $(\mathrm{cm})$ was measured at the same time with a ruler, with 20 readings in each paddock. The forage was cut at ground level and the collected samples were split into two sub-samples for determination of DM content. Botanical and structural components were separated manually into: leaf (blade), stem (leaf sheath + stem), dead material, inflorescence of Alexandergrass and other species. After botanical separation and drying of structural components, we determined the percentual participation of leaf blades, stems, inflorescences, dead material and other species. Next, we calculated the leaf: stem (L:S) ratio. 
Animals were weighed every 28 days, following a 12-hour fast from solids and liquids. The stocking rate (SR; $\mathrm{kg}$ / ha of live weight) was calculated by measuring the sum of the mean live weights of tester animals plus the average weight of animals used for adjustments in the stocking rate, multiplied by the number of days in the experimental unit, and divided by the number of days in the trial period.

The forage accumulation rate (FAR; $\mathrm{kg} / \mathrm{ha} /$ day of DM) was determined by using three exclusion cages located in each paddock. The forage allowance (FA; $\mathrm{kg}$ of DM of forage $/ \mathrm{kg}$ of body weight/day) was calculated by the equation: ((FM/no. days of period) + FAR)/SR of period. The green leaf blade allowance (GLBA) was obtained by multiplying FA by the average percentage of leaf blades in FM. In forage as grazed, the contents of DM, OM and MM (AOAC, 1995) as well as NDF were determined using polyester bags (according to modifications by KOMAREK, 1993), CP (ROBERTSON; VAN SOEST, 1981) and in situ digestibility of DM (ØRSKOV; MCDONALD, 1979).

The vertical structure of the canopy was evaluated in three representative areas of the forage mass in each experimental unit and sampling was carried out using $0.25 \mathrm{~m}^{2}$ squares. In each square, forage samples were taken every $10 \mathrm{~cm}$, from the top to the bottom of the sward, and separated manually into leaf blade, stem (leaf sheath + stem), dead material and inflorescence. The bulk density of each component (expressed as $\mathrm{g} / \mathrm{cm}^{3}$ ) was calculated using the proportion of component in each stratum and the forage mass.

Grazing, rumination and other activities were measured by direct visual observation every 10 minutes for 24 hours (JAMIESON; HODGSON, 1979). Grazing time was considered as the time spent selecting and apprehending forage, including the displacement intervals used for diet selection. Rumination time was considered the cessation of grazing and the initiation of chewing activity without searching for or apprehending forage. Other activities included when the animal remained at rest, drank water and interacted socially (FORBES, 1988). Activities were recorded as total time per day (min/day). Throughout the observation of grazing activity, we recorded the time taken to perform 20 bites, during the morning and afternoon, in order to calculate the bite rate (bites/min) (HODGSON, 1982). The daily number of bites (bites/day) was obtained by multiplying the bite rate by the daily grazing time ( $\mathrm{min} /$ day).

We also calculated the number and duration (in minutes) of meals and the interval between meals. A meal was considered a long sequence of grazing (CARVALHO; MORAES, 2005) with at least two successive 10-minute grazing periods. The minimum interval between meals was considered to be 20 minutes. These variables were calculated for each grazing shift, with the early hour shift corresponding to the interval between 1:00 and $6: 59 \mathrm{~h}$, the morning shift to the interval from 7:00 to $12: 59 \mathrm{~h}$, the afternoon shift to the interval from $13: 00$ to $18: 59 \mathrm{~h}$, and the night shift to the interval from 19:00 to $00: 59 \mathrm{~h}$.

The feeding station and displacement pattern evaluations were held during the diurnal grazing periods. For both evaluations, the grazing activity of the four heifers in each paddock was observed in five cycles of 10 feeding stations each. A feeding station was defined as the half-cylinder shaped area directly in front of and on each side of the animal when its front feet are stationary (LACA et al., 1992) and a footstep was defined as each movement of the forelegs. From these data, we calculated the number of feeding stations visited per minute, the time spent at each feeding station, the number of steps taken between each feeding station, the number of steps taken per minute (displacement), the number of feeding stations visited, and the number of steps taken during the daily grazing period.

For the pasture variables "ingestive behavior", "displacement pattern" and "meal dynamics", the data were analyzed in a completely randomized 
split-plot, with the amount of supplement $(0,0.80$, $1.12)$ as the main plots and the evaluation dates (January 25 and 28; February 25 and 28; March 23 and 24) as the subplots. For these evaluations, each animal was considered an experimental unit, and we used eight repetitions per treatment. For the pasture variables, the paddock was considered a repetition, with two area repetitions per treatment. Normally distributed variables were evaluated considering the amount of supplement, evaluation periods and their interactions as fixed effects, and the residual and heifers or paddocks nested in the supplement amounts as random effects.

The meal dynamics variables were also analyzed in grazing shifts, in a completely randomized design with a subdivided sub-plot structure. The amounts of supplement $(0,0.80,1.12)$ were the main plots, the evaluation dates (January 25 and 28; February 25 and 28; March 23 and 24) and assessment shifts were the subplots, and the heifers were the repetitions. We used a mixed model with fixed effects (the amounts of supplement, shifts and periods of assessment and their interactions) and random effects (the residual and the nested heifers for each amount of supplement).

Statistical analyses were performed using the MIXED procedure of the SAS software program, version 9.2. We performed a structure selection test using the Bayesian information criterion (BIC) to determine the model that best represented the data. The interaction between amount of supplement, evaluation periods and evaluation shift was significant at $5 \%$ probability. Whenever significant differences were found, mean values of the amounts of supplement, shifts and periods of assessment were compared using the lsmeans option at $10 \%$ probability. We used a stepwise procedure for multiple regression analysis to identify the most influential independent variables. From the equations obtained, we selected the one with the smallest $p$ value, residual variance and number of independent variables, and the highest determination coefficient.

\section{Results and Discussion}

The variables related to pasture were similar for all heifers across supplement amounts (Table 2), and we also ensured all animals had the same grazing conditions across treatments. The average values of forage mass and canopy height were 2771 $\mathrm{kg} \mathrm{DM} / \mathrm{ha}$ and $13.1 \mathrm{~cm}$, respectively.

This management strategy kept the heifers on similar leaf blade allowance $(3.1 \% \mathrm{BW})$, leaf blades (847.2 kg DM/ha), stem (1326.4 kg DM/ha), dead material (525.4 kg DM/ha) and inflorescence mass (42.9 kg DM/ha; Table 2). The percentages of leaf, stem, inflorescence and dead material were $31.3 \%, 48.3 \%, 18.8 \%$ and $1.6 \%$ of the forage mass, respectively.

The Alexandergrass leaf, stem, dead material and inflorescence bulk density were similar in the 0-10 and 10-20 cm strata in all paddocks, regardless of the amount of supplement provided (Table 3 ). The average bulk density of leaf, stem, dead material and inflorescence was 4.32, 9.99, 5.45 and $1.20 \mathrm{~g}$ of $\mathrm{DM} / \mathrm{cm}^{3}$ in the $0-10$ stratum and $1.20,0.97,0.17$ and $0.14 \mathrm{~g}$ of $\mathrm{DM} / \mathrm{cm}^{3}$ in the $10-20 \mathrm{~cm}$ stratum. The similar bulk densities of the pasture structural components across strata show that animals were subjected to similar structures for forage selection.

Rumination time was similar for heifers receiving different amounts of supplement, with an average of 431.21 minutes, which corresponds to $30 \%$ of daily activity. Rumination time is influenced by the consumption of neutral detergent fiber (WELCH; HOOPER, 1988) and is proportional to the cell wall content of forages (VAN SOEST, 1994). The heifers in the different supplement groups consumed forage with similar NDF content $(67.5 \% \mathrm{DM})$, in situ digestibility of DM $(57.9 \%$ DM) and CP (11.5\% DM) (Table 2), which explains the similar rumination time. Also, supplementation corresponded to 23 and $32 \%$ of the diet when heifers received 0.80 and $1.12 \% \mathrm{BW}$ of oat grain, respectively, considering their consumption as 3.5\% BW of DM per day. According to Rearte and Pieroni 
(2001), under these conditions, the ruminal $\mathrm{pH}$ is not modified, which means there is no change in ruminal flora or fiber degradability when ruminants are kept on high quality pasture and receive grain as a supplement at levels less than $35 \%$ of the total daily diet.

Table 2. Structural and qualitative characteristics of Alexandergrass grazed by beef heifers receiving different amounts of supplement.

\begin{tabular}{|c|c|c|c|c|}
\hline \multirow{2}{*}{ Variable } & \multicolumn{3}{|c|}{ Amount of oat grain included (\% of body weight) } & \multirow{2}{*}{$\mathrm{p}^{*}$} \\
\hline & 0 & 0.80 & 1.12 & \\
\hline Forage mass (kg of DM/ha) & $\begin{array}{c}2688.5 \\
( \pm 126.7)\end{array}$ & $\begin{array}{c}2892.5 \\
( \pm 126.6)\end{array}$ & $\begin{array}{c}2732.3 \\
( \pm 126.6)\end{array}$ & 0.556 \\
\hline Canopy height $(\mathrm{cm})$ & $\begin{array}{c}13.2 \\
( \pm 0.4)\end{array}$ & $\begin{array}{c}13.0 \\
( \pm 0.4)\end{array}$ & $\begin{array}{c}13.0 \\
( \pm 0.4)\end{array}$ & 0.910 \\
\hline Stocking rate (kg of BW/ha) & $\begin{array}{c}1997.1 \\
( \pm 198.1)\end{array}$ & $\begin{array}{c}2326.6 \\
( \pm 198.1)\end{array}$ & $\begin{array}{c}2494.1 \\
( \pm 198.1)\end{array}$ & 0.332 \\
\hline NDF $(\%$ of DM) & $\begin{array}{c}68.0 \\
( \pm 0.7)\end{array}$ & $\begin{array}{c}67.3 \\
( \pm 0.7)\end{array}$ & $\begin{array}{c}67.0 \\
( \pm 0.7)\end{array}$ & 0.644 \\
\hline $\mathrm{CP}(\%$ of $\mathrm{DM})$ & $\begin{array}{c}10.8 \\
( \pm 0.4)\end{array}$ & $\begin{array}{c}11.4 \\
( \pm 0.4)\end{array}$ & $\begin{array}{c}12.5 \\
( \pm 0.4)\end{array}$ & 0.120 \\
\hline $\mathrm{DDM}(\%$ of DM) & $\begin{array}{c}56.6 \\
( \pm 1.0)\end{array}$ & $\begin{array}{c}59.1 \\
( \pm 1.0)\end{array}$ & $\begin{array}{c}58.1 \\
( \pm 1.0)\end{array}$ & 0.370 \\
\hline Leaf blade allowance (\% of BW) & $\begin{array}{c}3.3 \\
( \pm 0.1)\end{array}$ & $\begin{array}{c}2.9 \\
( \pm 0.1)\end{array}$ & $\begin{array}{c}3.3 \\
( \pm 0.2)\end{array}$ & 0.206 \\
\hline Leaf mass (kg of DM/ha) & $\begin{array}{c}867.2 \\
( \pm 109.4)\end{array}$ & $\begin{array}{c}728.9 \\
( \pm 119.3)\end{array}$ & $\begin{array}{c}945.4 \\
( \pm 119.3)\end{array}$ & 0.511 \\
\hline Stem mass (kg of DM/ha) & $\begin{array}{l}1282.0 \\
( \pm 62.9)\end{array}$ & $\begin{array}{l}1235.8 \\
( \pm 67.4)\end{array}$ & $\begin{array}{c}1458.3 \\
( \pm 67.4)\end{array}$ & 0.167 \\
\hline Dead material mass (kg of DM/ha) & $\begin{array}{c}531.5 \\
( \pm 98.7)\end{array}$ & $\begin{array}{c}550.1 \\
( \pm 106.6)\end{array}$ & $\begin{array}{c}494.6 \\
( \pm 106.6)\end{array}$ & 0.933 \\
\hline Inflorescence mass (kg of DM/ha) & $\begin{array}{c}42.0 \\
( \pm 13.6)\end{array}$ & $\begin{array}{c}47.0 \\
( \pm 15.7)\end{array}$ & $\begin{array}{c}39.7 \\
( \pm 15.7)\end{array}$ & 0.947 \\
\hline
\end{tabular}

*Probability by lsmeans at 0.10 significance level; $\mathrm{NDF}=$ neutral detergent insoluble fiber; $\mathrm{CP}=$ crude protein; $\mathrm{DDM}=$ in situ digestibility of DM.

Exclusively grazing heifers remained 111 minutes $(29.72 \%)$ more than the grazing heifers receiving $0.80 \% \mathrm{BW}$ of supplement, while the time spent grazing by heifers that received $1.12 \%$ BW of supplement fell between the time spent by the other two groups (Table 4). The time spent at the trough (mean of 27.5 minutes) was similar ( $\mathrm{P}=$ 0.7401 ) for heifers that received different amounts of supplement. Heifers exclusively grazing and receiving $1.12 \% \mathrm{BW}$ of oat grains spent a similar amount of time performing other activities (527.5 minutes, on average). These heifers remained an additional 103.3 minutes (19.56\%) engaged in other activities than heifers that received $0.80 \% \mathrm{BW}$ of supplement. The higher nutrient contribution of the higher supplement supply may have motivated those animals to reduce the time devoted to grazing, since grazing time is regulated by activating mechanisms that control hunger and satiety (DOUGHERTY et al., 1988). This reduction in grazing time can be attributed to the increased harvesting efficiency of nutrients from pasture (KRYSL; HESS, 1993) that must have occurred when heifers received $0.80 \%$ BW of supplement. 
Table 3. Bulk density $\left(\mathrm{g}\right.$ of DM/ $/ \mathrm{cm}^{3}$ ) of the pasture structural components in the strata from 0 to $10 \mathrm{~cm}$ and 10 to $20 \mathrm{~cm}$.

\begin{tabular}{|c|c|c|c|c|}
\hline \multirow{2}{*}{ Variable } & \multicolumn{3}{|c|}{ Amount of oat grain included ( $\%$ of body weight) } & \multirow{2}{*}{$\mathrm{p}^{*}$} \\
\hline & 0 & 0.80 & 1.12 & \\
\hline & \multicolumn{3}{|c|}{$0-10 \mathrm{~cm}$} & \\
\hline Leaf & $\begin{array}{c}4.3 \\
( \pm 0.3)\end{array}$ & $\begin{array}{c}4.5 \\
( \pm 0.3)\end{array}$ & $\begin{array}{c}4.1 \\
( \pm 0.3)\end{array}$ & 0.619 \\
\hline Stem & $\begin{array}{c}9.6 \\
( \pm 1.0)\end{array}$ & $\begin{array}{c}10.3 \\
( \pm 1.0)\end{array}$ & $\begin{array}{c}10.1 \\
( \pm 1.0)\end{array}$ & 0.888 \\
\hline Dead Material & $\begin{array}{c}5.2 \\
( \pm 0.6)\end{array}$ & $\begin{array}{c}5.4 \\
( \pm 0.6)\end{array}$ & $\begin{array}{c}5.7 \\
( \pm 0.6)\end{array}$ & 0.812 \\
\hline \multirow[t]{2}{*}{ Inflorescence } & $\begin{array}{c}0.4 \\
( \pm 0.1)\end{array}$ & $\begin{array}{c}0.4 \\
( \pm 0.1)\end{array}$ & $\begin{array}{c}0.4 \\
( \pm 0.1)\end{array}$ & 0.971 \\
\hline & \multicolumn{3}{|c|}{$10-20 \mathrm{~cm}$} & \\
\hline Leaf & $\begin{array}{c}0.81 \\
( \pm 0.44)\end{array}$ & $\begin{array}{c}1.74 \\
( \pm 0.38)\end{array}$ & $\begin{array}{c}1.04 \\
( \pm 0.38)\end{array}$ & 0.357 \\
\hline Stem & $\begin{array}{c}0.58 \\
( \pm 0.50)\end{array}$ & $\begin{array}{c}1.13 \\
( \pm 0.46)\end{array}$ & $\begin{array}{c}1.21 \\
( \pm 0.46)\end{array}$ & 0.650 \\
\hline Dead Material & $\begin{array}{c}0.10 \\
( \pm 0.1007)\end{array}$ & $\begin{array}{c}0.17 \\
( \pm 0.0952)\end{array}$ & $\begin{array}{c}0.25 \\
( \pm 0.0952)\end{array}$ & 0.593 \\
\hline Inflorescence & $\begin{array}{c}0.09 \\
( \pm 0.0773)\end{array}$ & $\begin{array}{c}0.23 \\
( \pm 0.0669)\end{array}$ & $\begin{array}{c}0.11 \\
( \pm 0.0669)\end{array}$ & 0.426 \\
\hline
\end{tabular}

*Probability by $l$ smeans at 0.10 significance level.

Table 4. Ingestive behavior, displacement pattern and variables of short-term forage processes of beef heifers grazing Alexandergrass and receiving different amounts of supplement.

\begin{tabular}{|c|c|c|c|c|}
\hline \multirow{2}{*}{ Variable } & \multicolumn{3}{|c|}{ Amount of oat grain included ( $\%$ of body weight) } & \multirow{2}{*}{$\mathrm{p}^{*}$} \\
\hline & 0 & 0.80 & 1.12 & \\
\hline Grazing time (min) & $\begin{array}{l}484.7 \mathrm{a} \\
( \pm 19.3)\end{array}$ & $\begin{array}{l}373.6 \mathrm{c} \\
( \pm 20.3)\end{array}$ & $\begin{array}{l}434.1 \mathrm{~b} \\
( \pm 19.3)\end{array}$ & 0.003 \\
\hline Other activities (min) & $\begin{array}{l}539.4 \mathrm{~b} \\
( \pm 32.3)\end{array}$ & $\begin{array}{l}630.8 \mathrm{a} \\
( \pm 32.3)\end{array}$ & $\begin{array}{l}515.6 \mathrm{~b} \\
( \pm 32.3)\end{array}$ & 0.056 \\
\hline Bite rate (bites/min) & $\begin{array}{l}44.2 \mathrm{a} \\
( \pm 0.9)\end{array}$ & $\begin{array}{l}44.3 \mathrm{a} \\
( \pm 1.0)\end{array}$ & $\begin{array}{l}41.2 \mathrm{~b} \\
( \pm 0.9)\end{array}$ & 0.037 \\
\hline Time per feeding station(s) & $\begin{array}{l}10.1 \mathrm{~b} \\
( \pm 0.7)\end{array}$ & $\begin{array}{l}10.4 \mathrm{~b} \\
( \pm 0.7)\end{array}$ & $\begin{array}{l}12.1 \mathrm{a} \\
( \pm 0.7)\end{array}$ & 0.094 \\
\hline Steps per minute & $\begin{array}{l}11.2 \mathrm{a} \\
( \pm 0.6)\end{array}$ & $\begin{array}{l}12.1 \mathrm{a} \\
( \pm 0.7)\end{array}$ & $\begin{array}{l}9.7 \mathrm{~b} \\
( \pm 0.6)\end{array}$ & 0.053 \\
\hline Daily feeding stations & $\begin{array}{l}3381.1 \mathrm{a} \\
( \pm 171.5)\end{array}$ & $\begin{array}{l}2594.6 \mathrm{~b} \\
( \pm 183.5)\end{array}$ & $\begin{array}{l}2632.7 \mathrm{~b} \\
( \pm 171.5)\end{array}$ & 0.006 \\
\hline Total steps & $\begin{array}{l}5383.9 \mathrm{a} \\
( \pm 345.1)\end{array}$ & $\begin{array}{c}4569.6 \mathrm{ab} \\
( \pm 371.5)\end{array}$ & $\begin{array}{l}4235.4 \mathrm{~b} \\
( \pm 345.1)\end{array}$ & 0.076 \\
\hline Number of meals & $\begin{array}{l}9.8 \mathrm{a} \\
( \pm 0.5)\end{array}$ & $\begin{array}{l}7.4 \mathrm{~b} \\
( \pm 0.5)\end{array}$ & $\begin{array}{c}8.0 \mathrm{~b} \\
( \pm 0.5)\end{array}$ & 0.005 \\
\hline Interval duration (min) & $\begin{array}{l}99.1 \mathrm{~b} \\
( \pm 3.7)\end{array}$ & $\begin{array}{l}142.5 \mathrm{a} \\
( \pm 3.9)\end{array}$ & $\begin{array}{c}131.9 \mathrm{a} \\
( \pm 3.7)\end{array}$ & 0.005 \\
\hline
\end{tabular}

*Probability by lsmeans at 0.10 significance level. 
Heifers exclusively grazing had a similar bite rate than those receiving $0.80 \% \mathrm{BW}$ supplement (44.2 bites/minute). These heifers performed 3.1 bites per minute $(7.53 \%)$ more than heifers receiving $1.12 \% \mathrm{BW}$ supplement. The additional $0.32 \% \mathrm{BW}$ of oat grain provided heifers with greater selectivity in the choice of bite location, because greater energy supplies via supplementation cause heifers to select more leaf blades in an attempt to maintain the energy: protein ratio (PROVENZA; LAUCHBAUNGH, 1999). The observed bite rate values were within the range found in previous studies (BRÂNCIO et al., 2003; PALHANO et al., 2007), that is, between 20 and 50 bites per minute for tropical forage grasses.

When they receive different amounts of supplement, heifers perceive similar structural conditions of pasture as being different. The grazing time of the heifers receiving no supplement was influenced by the bulk density of the inflorescence in the upper stratum (Alexandergrass grazing time $\left.=451.52+361,14 \mathrm{INF} 2 ; \mathrm{P}=0.086 ; \mathrm{r}^{2}=0.69\right)$; the time allocated to other activities by these heifers was influenced by the leaf blade mass (Alexandergrass other activities time $=287.70+0.28$ LBM; $\mathrm{P}=$ $\left.0.021 ; r^{2}=0.87\right)$ and the bite rate was influenced by the canopy height (Alexandergrass bite rate $=24.35$ $\left.+1.50 \mathrm{CH} ; \mathrm{P}=0.009 ; \mathrm{r}^{2}=0.85\right)$. The emission of inflorescence by tillers reflects plant tissue age and decreasing pasture quality. Under these conditions, it is more difficult to prehend leaf blades. This increases the time heifers spend searching for leaf blades and decreases the time they spend on other activities, probably because most of their nutritional requirements come exclusively from ingesting grass. The variation in the structural composition of vertical strata from the top to the bottom of the sward is reflected in the accessibility to the leaf blades and determines the ease or difficulty of prehending these leaves (CARVALHO; MORAES, 2005).

The grazing time of heifers receiving $0.80 \% \mathrm{BW}$ of oat grain was influenced by the bulk density of stems in the lower canopy stratum (stem 1, 0-10 $\mathrm{cm})$; (Grazing time $0.80 \% \mathrm{BW}=308.98+53.04$ stem $\left.1 ; \mathrm{P}=0.004 ; \mathrm{r}^{2}=0.95\right)$ and the bite rate was influenced by stocking rate (Bite rate $0.80 \% \mathrm{BW}$ $\left.=34.582+0.004 \mathrm{SR} ; \mathrm{P}=0.034 ; \mathrm{r}^{2}=0.82\right)$. The time devoted to other activities by heifers receiving $1.12 \%$ BW of supplement was influenced by the bulk density of stems in the upper canopy stratum (time spent on other activities $1.12 \% \mathrm{BW}=621.84$ - 100.35 stem $2 ; \mathrm{P}=0.028 ; \mathrm{r}^{2}=0.94$ ) and the bite rate was influenced by the stem mass (bite rate $1.12 \% \mathrm{BW}=63.943-.019$ stem; $\mathrm{P}=0.044 ; \mathrm{r}^{2}=$ $0.79)$. The presence of stems in the grazing stratum provides a barrier to the selection of leaf blades and bite apprehension (SOLLENBERGER; BURNS, 2001), which leads heifers to increase the time devoted to grazing with the aim of selecting the leaf blade component (STOBBS, 1975). The stems interfere with access to leaf blades and can reduce bite depth (BENVENUTTI et al., 2006). As a way to avoid the stems, heifers perform more selective bites and decrease bite rate, as well as the time devoted to other activities (Table 4). This results in an increase in grazing time, when compared to heifers receiving $0.80 \% \mathrm{BW}$ supplement or no supplement. The animal tries to adjust its ingestive behavior to maintain stable forage intake, even with the variation in pasture management (CARVALHO et al., 2001). Thus, increasing the stocking rate for the same forage mass can reduce the bite mass and increase bite rate.

The heifers that received $1.12 \% \mathrm{BW}$ of oat grain remained 1.63 minutes (15.90\%) longer in each feeding station and took 1.98 fewer steps per minute $(20.45 \%)$ than the heifers exclusively on pasture and the ones receiving $0.80 \% \mathrm{BW}$ of supplement. These values characterize the heifers' higher selectivity, according to Carvalho et al. (1999). The number of feeding stations visited per minute (6.76), the number of bites taken at each feeding station (6.84) and the number of steps taken between feeding stations (1.69 steps) were similar across animals receiving different amounts of supplement. The similarity observed for the last two variables can 
be explained by the fact that the canopy structure was similar across paddocks (Table 2). The bite rate is related to the structure of the pasture and the displacement between feeding stations is related to the last bite taken in the previous feeding station (CARVALHO; MORAES, 2005).

The time spent at each feeding station and the displacement of heifers exclusively grazing was explained by in situ DM digestibility of forage as grazed (Alexandergrass time per feeding station $=38.15-0.49$ DDM; $\mathrm{P}=0.032 ; \mathrm{r}^{2}=0.83$ and Alexandergrass steps per minute $=-16.27+0.49$ DISMS; $\left.\mathrm{P}=0.019 ; \mathrm{r}^{2}=0.78\right)$. The leaf blade allowance (LBA) was the main determinant of time spent in each feeding station and of the displacement of heifers supplemented with 1.12\% BW (time per feeding station $1.12 \% \mathrm{BW}=18.59-1.12 \mathrm{LBA} ; \mathrm{P}=$ $0.008 ; \mathrm{r}^{2}=0.98$ and steps per minute $1.12 \% \mathrm{BW}=$ $0.98+2.96$ LBA; $p=0.001 ; r^{2}=0.98$, respectively), highlighting the demand and preference for this plant structure in the canopy. The leaf blade is the plant component with the highest digestibility, and a greater leaf blade allowance leads to easier forage apprehension. A greater proportion of leaf blades allows supplemented as well as non-supplemented heifers to remain for less time in each feeding station and perform larger displacements. Oliveira Neto et al. (2013) observed that lower leaf blade allowances led heifers to increase selection time in the feeding station and decrease displacement.

The number of feeding stations visited per day did not differ significantly between heifers supplemented with 0.80 and $1.12 \%$ BW of oat grain $(2,613.7$, on average). Heifers exclusively grazing visited an additional 741.2 feeding stations (28.08\%) during the daily grazing period than heifers receiving supplement. For these animals, the combination of increased grazing time with an intermediate number of feeding stations visited per minute resulted in the largest number of visited feeding stations. Compared to heifers receiving $1.12 \%$ BW of supplement, exclusively grazing heifers performed 1148.5 (27.12\%) more steps during the grazing period, while heifers receiving $0.80 \%$ BW of supplement did not differ from the $1.12 \%$ group. Animals move to increase their chances of encountering potential bites and change their daily search strategies in order to maintain adequate levels of forage consumption. Heifers exclusively grazing have compensatory feeding strategies to increase forage intake compared to those that receive supplement. Regardless of the amount of supplement provided, the heifers in this study obtained a similar average daily weight gain of $0.718 \mathrm{~kg}$.

Heifers exclusively grazing consumed 1.8 $(27.27 \%)$ more meals and their interval between meals was 48.13 minutes $(46.10 \%)$ lower than the heifers that received either amount of supplement (Table 2). Heifers receiving either amount of supplement did not differ from each other in terms of meal duration (57.26 minutes, on average). The number of meals is linked to the sward environment and pasture management (GREGORINI, 2012). The beginning of the next meal in animals kept under continuous grazing is motivated by their empty gastro-intestinal tract (GREGORINI et al., 2008). Supplementation makes heifers consume a lower number of meals because the supplement provides greater ruminal fill and increases the feeling of satiety; this, in turn, increases the time interval between meals. The duration of the meal, similar in all feeding systems, is connected to the structural attributes of the sward. The similarity of the canopy structure (Table 2) in different feeding systems allowed heifers to maintain similar meal durations. There was no interaction between the amount of supplement and meal shifts for the interval between meals $(\mathrm{P}=0.397)$. The interval between meals was greater at night (236.59 minutes; $\mathrm{P}=0.002)$, followed by the early hours (194.82 minutes), morning (128.66 minutes), and the afternoon (67.58 minutes). This is a primitive ruminant behavior, which concentrates grazing during the daytime in order to limit exposure to predators (ROCHE et al., 2008). 
We observed an interaction between the amount of supplement and the meal shifts for the number of meals $(\mathrm{P}=0.028)$ and duration of each meal ( $\mathrm{P}$ $<0.0001$; Table 5). Regardless of the amount of supplement consumed, heifers performed a similar number of meals in the early hour, morning and night shifts, with mean values of 1.9, 2.7 and 1.2 meals, respectively. In contrast, the amount of supplement affects the number of meals performed by heifers in the afternoon: heifers that remained exclusively on pasture consumed 1.58 (71.49\%) more meals than heifers receiving $0.80 \% \mathrm{BW}$ of oat grain. Heifers receiving $1.12 \% \mathrm{BW}$ of supplement consumed an intermediate number of meals (Table 5). Animals exclusively grazing consumed meals more frequently than supplemented heifers. This behavior is associated with the concentration of circulating metabolites (i.e., the metabolic energy concentration), which provides orexigenic signals to the neurohormonal system, signaling the start of a new meal (ROCHE et al., 2008). In the early hour and morning shifts, regardless of the amount of supplement offered, heifers had meals that lasted a similar amount of time (44.1 and 51.8 minutes, respectively). In the afternoon, the heifers that received $1.12 \% \mathrm{BW}$ of oat grain spent 29 minutes $(50.04 \%)$ more on each meal than the heifers in either of the other groups. During the night shift, the heifers receiving $1.12 \%$ BW supplement remained 29.1 minutes $(60.95 \%)$ more at each meal than those exclusively grazing. Heifers that received $0.80 \% \mathrm{BW}$ of oat grain remained at each meal for a similar amount of time than those of the other groups.

Table 5. Meal dynamics in grazing shifts of heifers in Alexandergrass pasture receiving different amounts of supplement.

\begin{tabular}{|c|c|c|c|c|c|}
\hline \multirow{2}{*}{$\begin{array}{l}\text { Amount of oat grain included } \\
\text { ( } \% \text { of body weight })\end{array}$} & \multicolumn{4}{|c|}{ Daily shift } & \multirow{2}{*}{$\mathrm{P}^{*}$} \\
\hline & Early hour ${ }^{1}$ & Morning $^{2}$ & Afternoon $^{3}$ & Night $^{4}$ & \\
\hline & \multicolumn{5}{|c|}{ Number of meals } \\
\hline 0 & $\begin{array}{c}2.2 \mathrm{a} \\
( \pm 0.2)\end{array}$ & $\begin{array}{c}2.8 \mathrm{a} \\
( \pm 0.2)\end{array}$ & $\begin{array}{c}3.8 \mathrm{a} \\
( \pm 0.2)\end{array}$ & $\begin{array}{l}1.3 \mathrm{a} \\
( \pm 0.2)\end{array}$ & \\
\hline 0.80 & $\begin{array}{c}1.8 \mathrm{a} \\
( \pm 0.2)\end{array}$ & $\begin{array}{c}2.7 \mathrm{a} \\
( \pm 0.2)\end{array}$ & $\begin{array}{l}2.2 \mathrm{c} \\
( \pm 0.2)\end{array}$ & $\begin{array}{l}1.2 \mathrm{a} \\
( \pm 0.2)\end{array}$ & 0.010 \\
\hline \multirow[t]{2}{*}{1.12} & $\begin{array}{c}2.0 \mathrm{a} \\
( \pm 0.2)\end{array}$ & $\begin{array}{c}2.6 \mathrm{a} \\
( \pm 0.2)\end{array}$ & $\begin{array}{c}2.7 \mathrm{~b} \\
( \pm 0.2)\end{array}$ & $\begin{array}{l}1.1 \mathrm{a} \\
( \pm 0.2)\end{array}$ & \\
\hline & \multicolumn{5}{|c|}{ Meal duration (min.) } \\
\hline 0 & $\begin{array}{l}54.6 \mathrm{a} \\
( \pm 7.9)\end{array}$ & $\begin{array}{l}51.7 \mathrm{a} \\
( \pm 7.7)\end{array}$ & $\begin{array}{l}50.0 \mathrm{~b} \\
( \pm 7.7)\end{array}$ & $\begin{array}{l}47.8 \mathrm{~b} \\
( \pm 8.2)\end{array}$ & \\
\hline 0.80 & $\begin{array}{l}32.9 \mathrm{a} \\
( \pm 9.4)\end{array}$ & $\begin{array}{l}59.4 \mathrm{a} \\
( \pm 8.4)\end{array}$ & $\begin{array}{l}58.0 \mathrm{~b} \\
( \pm 8.2)\end{array}$ & $\begin{array}{c}66.9 \mathrm{ab} \\
( \pm 8.2)\end{array}$ & 0,011 \\
\hline 1.12 & $\begin{array}{l}44.5 \mathrm{a} \\
( \pm 8.6)\end{array}$ & $\begin{array}{l}44.3 \mathrm{a} \\
( \pm 7.7)\end{array}$ & $\begin{array}{l}87.0 \mathrm{a} \\
( \pm 7.7)\end{array}$ & $\begin{array}{l}76.9 \mathrm{a} \\
( \pm 8.2)\end{array}$ & \\
\hline
\end{tabular}

*Interaction probability between amounts of oat grains x shifts $(0.05$ significance level $)$ by $l$ smeans; ${ }^{1}$ Early hour $=1: 00$ to $6: 59 \mathrm{~h}$; ${ }^{2}$ Morning $=7: 00$ to $12: 59 \mathrm{~h} ;{ }^{3}$ Afternoon $=13: 00$ to $18: 59 \mathrm{~h} ;{ }^{4} \mathrm{Night}=19: 00$ to $00: 59 \mathrm{~h}$.

The higher meal duration during the afternoon and night periods for heifers receiving $1.12 \% \mathrm{BW}$ of oat confirms the higher selectivity of these animals, considering the diurnal fluctuations in the chemical composition of forages. These fluctuations are especially noticeable in the accumulation rate of photosynthates during the afternoon and night due to water loss via 
transpiration, which leads to an increase in the concentration of nutrients during this period (relative to the morning period), thus increasing the quality of forage consumed (GREGORINI, 2012).

\section{Conclusions}

In a similar sward structure, ingestive behavior, displacement patterns, as well as the dynamics of daily meals and shifts, are modified when heifers grazing Alexandergrass receive oat grain in different amounts. Heifers receiving 1.12\% BW of oat grain remain longer at each feeding station and perform a lower number of steps per minute. Heifers exclusively on pasture spend more time grazing and have a higher number of daily meals with shorter inter-meal intervals. In this study, we used multiple regression equations to analyze pasture attributes in order to create a predictive model of ingestive behavior and forage selection patterns in beef heifers on Alexandergrass pasture receiving different amounts of supplement.

\section{References}

ASSOCIATION OF OFFICIAL ANALYTICAL CHEMISTS - AOAC. Official methods of analysis. $16^{\text {th }}$ ed. Washington, D. C., 1995. 1025 p.

BAUMONT, R.; PRACHE, S.; MEURET, M.; MORAND-FEHR, P. How forage characteristics influence behaviour and intake in small ruminants: review. Livestock Production Science, Zaragoza, v. 64, n. 52, p. 11-25, 2000.

BENVENUTTI, M. A.; GORDON, I. J.; POPPI, D. P. The effect of the density and physical properties of grass stems on the foraging behaviour and instantaneous intake rate by cattle grazing an artificial reproductive tropical sward. Grass and Forage Science, Oxford, v. 61, n. 3, p. 272-281, 2006.

BRÂNCIO, P. A.; EUCLIDES, V. P. B.; NASCIMENTO JUNIOR, D. Avaliação de três cultivares de Panicum maximum Jacq. sob pastejo: comportamento ingestivo de bovinos. Revista Brasileira de Zootecnia, Viçosa, MG, v. 32, n. 5, p. 1045-1053, 2003.
CARVALHO, P. C. F.; PRACHE, S.; DAMASCENO, J. C. O. Processo de pastejo: desafios da procura e apreensão da forragem pelo herbívoro. In: REUNIÃO ANUAL DA SOCIEDADE BRASILEIRA DE ZOOTECNIA, 36., 1999, Porto Alegre. Anais... Porto Alegre: UFRGS. Faculdade de Agronomia. p. 253-268, 1999.

CARVAlHO, P. C. F.; MORAES, A. Comportamento ingestivo de ruminantes: bases para o manejo sustentável do pasto. In: SIMPÓSIO SOBRE MANEJO SUSTENTÁVEL DAS PASTAGENS, 2005, Maringá. Anais... Maringá: UEM, 2005. CD-ROM.

CARVALHO, P. C. F.; RIBEIRO FILHO, H. M. N.; POLI, C. H. E. C.; MORAES, A.; DELAGARDE, R. Importância da estrutura da pastagem na ingestão e seleção de dietas pelo animal em pastejo. In: MATTOS, Wilson Roberto Soares. A produção animal na visão dos brasileiros. Piracicaba: Fundação de Estudos Agrários Luiz de Queiroz, 2001. p. 853-871.

COSTA, V. G.; ROCHA, M. G.; PÖTTER, L.; ROSO, D.; ROSA, A. T. N.; REIS, J. Comportamento de pastejo e ingestão de forragem por novilhas de corte em pastagens de milheto e papuã. Revista Brasileira de Zootecnia, Viçosa, MG, v. 40, n. 2, p. 251-259, 2011.

DOUGHERTY, C. D.; BRADLEY, N. W.; CORNELIUS, P. L.; LAURIAUT, L. M. Expression of the regulation of energy balance on the ingestive behavior of grazing beef cattle supplemented by grain. Applied Animal Behaviour Science, Amsterdam, v. 20, n. 3, p. 227-236, 1988.

EMPRESA BRASILEIRA DE PESQUISA AGROPECUÁRIA - EMBRAPA. Centro Nacional e Pesquisa em Solos. Sistema Brasileiro de Classificação de Solos. Brasília: Embrapa-SPI; Rio de Janeiro: EmbrapaSolos, 2006. 306 p.

FORBES, T. A. D. Researching the plant-animal interface: the investigation of ingestive behaviour of cows and sheep. Journal of Animal Science, Champaign, v. 66, n. 9 , p. $2369-2379,1988$.

GREGORINI, P. Diurnal grazing pattern: its physiological basis and strategic management. Animal Production Science, v. 52, n. 7, p. 416-430, 2012.

GREGORINI, P.; GUNTER, S. S. A.; BECK, P. A.; SODER, K. J.; TAMMINGA, T. Review: the interaction of diurnal grazing pattern, ruminal metabolism, nutrient supply, and management in cattle. The Professional Animal Scientist, Nova Orleans, v. 24, n. 4, p. 308-318, 2008.

HERINGER, I.; CARVALHO, P. C. F. Ajuste da carga animal em experimentos de pastejo: uma nova proposta. Ciência Rural, Santa Maria, v. 32, n. 4, p. 675-679, 2002. 
HODGSON, J. Ingestive behavior. In: LEAVER, J. D. (Ed.). Herbage intake handbook. Hurley: British Grassland Society, 1982. p. 113-138.

JAMIESON, W. S.; HODGSON, J. The effect of daily herbage allowance and sward characteristics upon the ingestive behaviour of calves under strip-grazing management. Grass and Forage Science, Oxford, v. 34, n. 4, p. 261-271, 1979.

KOMAREK, A. R. A fiber bag procedure for improved efficiency of fiber analyses. Journal of Dairy Science, Champaing, v. 76, n. 1, p. 250-259, 1993.

KRYSL, L. J.; HESS, B. W. Influence of supplementation on behavior of grazing cattle. Journal of Animal Science, Champaign, v. 71, n. 9, p. 2546-2555, 1993.

LACA, E. A.; UNGAR, E. D.; SELIGMAN, N. Effects of sward height and bulk density on bite dimensions of cattle grazing homogeneous sward. Grass and Forage Science, Oxford, v. 47, n. 1, p. 91-102, 1992.

OLIVEIRA NETO, R. A.; SILVA, J. H. S.; ROCHA, M. G.; PÖTTER, L.; SICHONANY, M. J. O.; BISCAÍNO, L. L.; SANTO, F. A.; DIFANTE, M. V. B. Ingestive behavior, performance and forage intake by beef heifers on tropical pasture systems. Revista Brasileira de Zootecnia, Viçosa, MG, v. 42, n. 8, p. 549-558, 2013.

ØRSKOV, E. R.; McDONALD, I. The estimation of protein degradability in the rumen from incubation measurements weighed according to rate of passage. Journal of Agricultural Science, Cambridge, v. 92, n. 2, p. 499-503, 1979.

PALHANO, A. N.; CARVALHO, P. C. F.; DITTRICH, J. R. Características do processo de ingestão de forragem por novilhas holandesas em pastagens de capimmombaça. Revista Brasileira de Zootecnia, Viçosa, MG, v. 36, n. 4, p. 1014-1021, 2007.
PROVENZA, F. D.; LAUCHBAUNGH, K. L. Foraging on the edge of chaos. In: LAUCHBAUNGH, K. L.; MOSLEY, J. C.; SANDERS, K. D. (Ed.). Grazing behavior of livestock and wildlife. Moscow: University of Idaho, 1999. p. 1-12.

REARTE, D. H.; PIERONI, G. A. Supplementation of temperate pastures. In: INTERNATIONAL GRASSLAND CONGRESS, 19., 2001, Piracicaba. Proceedings... São Pedro: SBZ, 2001. p. 679-689.

ROBERTSON, J. B.; VAN SOEST, P. J. The detergent system of analysis. In: JAMES, W. P. T.; THEANDER, O. (Ed.). The analysis of dietary fiber in food. New York: Marcel Dkker, 1981. Chapter 9, p. 123-158.

ROCHE, J. R.; BLACHE, D.; KAY, J. K.; MILLER, D. R.; SHEAHAN, A. J.; MILLER, D. V. Neuroendocrine and physiological regulation of intake with particular reference to domesticated ruminant animals. Nutrition Research Reviews, Cambridge, v. 21, n. 2, p. 207-234, 2008.

SOLLENBERGER, L. E.; BURNS, J. C. Canopy characteristics, ingestive behavior and herbage intake in cultivated tropical grasslands. In: INTERNATIONAL GRASSLAND CONGRESS, 2001, São Pedro. Proceedings... São Pedro: SP, 2001. v. 19, p. 321-327.

STOBBS, T. H. Factors limiting the nutritional value of grazed tropical pastures for beef and milk production. Tropical Grasslands, Brisbane, v. 9, n. 2, p. 141-150, 1975.

VAN SOEST, P. J. Nutritional ecology of the ruminant. $2^{\text {th }}$ ed. Ithaca: Cornell University Press, 1994. 476 p.

WELCH, J. G.; HOOPER, A. P. Ingestion of feed and water. In: CHURCH, D. C. (Ed.). The ruminant animal: digestive physiology and nutrition. Reston: Englewood Cliffs, 1988. p. 108-116. 